Conference Paper

\title{
The Effect of Product Quality on Customer Loyalty with Customer Trust and Customer Satisfaction as Intervening Variables in Using Consumer Credit at Bank BJB - Surabaya Branch Office
}

\author{
Eko Purwanto*, Fani Rachma Hapsari
}

Economic Departement Faculty of Economic and Business, Universitas Pembangunan Nasional "Veteran" Jawa Timur, Surabaya 60294, Indonesia

*Corresponding author:

E-mail: ekopasca@upnjatim.ac.id

\begin{abstract}
The study of marketing strategies on improving product quality carried out by Bank BJB was carried out to examine whether this creates a sense of trust and customer satisfaction to make them loyal customers in using BJB bank products. Consumer loans are loans that are consumptive for permanent employees with payment from income. The sample in this study were 98 consumer credit customers at Bank BJB - Surabaya Branch took by simple random sampling technique and the calculation of the Slovin formula. The research data consisted of primary and secondary data. Primary data was obtained from questionnaires and secondary data was obtained from the company. The analytical tool used in the present research was Partial Least Square (PLS). The results of this study indicated that product quality contributed to customer satisfaction and trust and resulted in inconvenience to customers. Customer satisfaction and trust contributed to customer loyalty.
\end{abstract}

Keywords: Product quality, customer satisfaction, customer trust, customer loyalty, consumer credit

\section{Introduction}

Consumer credit facilities currently provide a very large contribution for every bank including Bank BJB. One of the most demanded products of Bank BJB is Guna Bhakti Credit (KGB), where credit returns come from the income received by the debtor monthly. This credit is only given to a group of debtors who have a fixed income whose income is channeled through the bank and where the debtor works and has a partnership with the bank so that the credit return is guaranteed. This credit is usually used for consumptive purposes. Based on data, the number of customers of Bank BJB-Surabaya branch in 2016 - 2019 is shown in the following table 1.

Table 1. The number of consumer credit customers at BJB Bank Surabaya Branch Office

\begin{tabular}{ccccc}
\hline \multirow{2}{*}{ No } & \multirow{2}{*}{ Year } & NOA & Consumer Credit Products \\
& & 4.596 & Rise & G (\%) \\
\hline 1 & 2016 & 6.809 & 2.213 & - \\
2 & 2017 & 8.169 & 1.360 & $33 \%$ \\
3 & 2018 & 9.895 & 1.726 & $16.6 \%$ \\
4 & 2019 & & $17.4 \%$ \\
\hline
\end{tabular}

Source: Bank BJB - Surabaya Branch Office, 2019

How to cite:

Purwanto, E., \& Hapsari, F. R. (2021). The effect of product quality on customer loyalty with customer trust and customer satisfaction as intervening variables in using consumer credit at Bank BJB - Surabaya Branch Office. $3^{\text {rd }}$ Economics, Business, and Government Challenges 2020. NST Proceedings. pages 6-12. doi: 10.11594/ nstp.2021.1302 
The number of Bank BJB consumer credit customers at Surabaya Branch Office increases every year. However, the increase was not optimal with the addition of 2,213 NOA (Number of Accounts) customers in 2017 (33\%) from 2016. The increase also occurred in 2018 but was lower (16.6\%) compared to that of the previous year. In 2019 there was an increase of 1,726 NOA (number of accounts) and this number was stagnant and almost similar to that of 2018 (17.4\%). Several factors are influencing the percentage, one of which is market saturation that which becomes a concern for the management of Bank BJB to find out and identify the biggest factor that causes a decrease in the percentage of the number of customers. It is necessary to see whether this decline is affected by unsatisfactory product quality or other factors. Also, the decrease in the number of customers is an indicator for the Bank BJB Surabaya Branch Office to find out whether from 2016 to 2019, customers owned by Bank BJB Surabaya Branch Offices, especially credit customers, our loyal customers.

One of the efforts to increase the number of consumer credit customers is the right marketing strategy so that market share can be maintained and even increased amidst intense competition. The right strategy requires a study of marketing strategies including product quality improvement which has been implemented by Bank BJB at Surabaya Branch Office. This is to see if the product has met customer satisfaction. One of the credit products of Bank BJB at the Surabaya Branch Office is Consumer Credit. Consumer Loans are consumptive loans and are intended for employees with fixed income whose salaries have been channeled through bank BJB or not which can be used for various purposes with the main source of payment coming from the income concerned. The advantages of this product are easy requirements and a fast credit disbursement process so that it is a product that is sought after by customers so that it becomes the main pillar in the BJB Bank business.

From the above discussion, the researcher is interested in researching Bank BJB Surabaya Branch Office with one of the main pillars of consumer credit. The title taken is the Effect of Product Quality on Customer Loyalty with Customer Trust and Customer Satisfaction as Intervening Variables in Using Consumer Credit at Bank BJB Surabaya Branch Office.

\section{Literature review Product quality}

According to Kotler and Keller (2009) "Product quality is the characteristic of a product or service that bears on its ability to satisfy stated or implied customer needs". "Appropriateness in using a product is if the product has long durability of use, the product used will improve the image or status of consumers who use it, the product is not easily damaged, there is quality assurance and is ethical if used. "

\section{Customer satisfaction}

According to Kotler in Lupiyoadi (2006) "customer satisfaction is the level of feeling where a person states the results of the comparison of the performance of the product or service received as expected". According to Howard and Sheth in Tjiptono and Chandra (2005) "customer satisfaction is the buyer's cognitive situation about the equivalence or mismatch between the results obtained compared to the sacrifices made". Customer satisfaction according to Parasuranman et al. (1985) is a custom assessment of a product or service in terms of assessing whether the product or service has met customer needs and expectations.

\section{Customer trust}

Trust is a company's willingness to depend on business partners (Kotler \& keller, 2009). The definition of trust is the confidence that one will find what is designed from another, rather than what is feared. 


\section{Customer loyalty}

The customer loyalty is defined as a customer commitment to a brand, store/supplier based on a very positive attitude and is reflected in consistent repeat purchases. The customer loyalty is the strength of the relationship between the relative attitude of an individual to a unity (brand, service, store, or supplier) and repurchase. Loyalty according to Tjiptono (2000) is a situation where consumers have a positive attitude towards the product or producer (service/product provider) and are accompanied by a consistent repurchase pattern. Consumer loyalty is a frame of mind for consumers who hold a preferred attitude towards a company, are committed to buying more of the company's products/services and recommending these products/services.

\section{Method}

\section{Research approach}

This is quantitative research i.e. research that analyzes data quantitatively or statistically to test the predetermined hypothesis and then interpreting the results of the analysis to obtain a conclusion (Sugiyono, 2014). The sample in this study is consumer credit customers at bank BJB Surabaya Branch Office in 2016 - 2019.

\section{Operational definition}

\section{a. Product Quality}

The ability of a product to demonstrate its functions including overall durability, reliability, accuracy, ease of operation, and product repair are also other product attributes. The dimensions of product quality that have been described above are for physical products, while for products that are services or services the author refers to Garvin's explanation.

b. Customer satisfaction

This is the customer responsibility to evaluating the perceived mismatch between previous expectations and the actual performance of the product after use. There are 3 (three) important aspects that need to be examined in the framework of measuring customer satisfaction.

\section{c. Customer trust}

It is the belief that someone will find what they want in an exchange partner. Trust involves a person's willingness to behave a certain way because of the belief that his partner will give him what he hopes for and an expectation that someone generally has that the words, promises, or statements of others can be trusted.

\section{d. Customer loyalty}

Shows the tendency of customers to use a certain brand with a high level of consistency. This means that loyalty is always related to customer preferences and actual purchases. The customer loyalty variable is measured by 3 (three) indicator items.

\section{Results and Discussion \\ Effect of product quality on customer satisfaction}

Based on statistical tests, the variable product quality proved to have a positive effect on customer satisfaction. This may indicate that the better the quality of consumer credit products at Bank BJB at the Surabaya Branch, the more customer satisfaction will be. The quality of Bank BJB consumer credit products at the Surabaya Branch Office can provide distinctive features and product characteristics to customers so that customers have the perception that Bank BJB consumer credit products have certain advantages that other products do not. Customers who feel that the product has characteristics and characteristics that are different from other products can fulfill their wants and needs, resulting in satisfaction. 
The customer is an assessor of the quality of a banking product. There are many measurements that customers can use in determining the quality of a banking product. However, the final goal achieved is the same, namely to be able to provide satisfaction to customers. The more satisfied a customer is in consuming a banking product, the more quality the banking product will be. Satisfaction or dissatisfaction of a customer is determined by the suitability of customer expectations with customer perceptions of the actual performance of the product. Customers are satisfied if the bank can provide product quality that matches customer expectations. Customers form their expectations of the supposed performance of a product. Performance expectations are compared with the actual performance of banking products. If the actual performance is greater than or equal to expectations, customer satisfaction emerges.

\section{The effect of product quality on customer trust}

The product quality variable is proven to have a positive effect on customer trust. This indicates that the better the quality of consumer credit products provided by Bank BJB Surabaya Branch, the higher customer confidence. The results showed that the variable product quality consisting of characteristics, features, excellence, convenience following customer expectations, and needs had a significant effect on trust. By displaying the quality of the products produced, customers have more confidence in these products. Good quality generates trust in the minds of customers not to switch to other products.

Bank BJB- which has good quality consumer credit products- will be able to make customers believe in the product. Trust in the output and outcome of consumer credit products has an impact on consumer purchasing decisions. Quality is a matter that is considered or decided by the customer, meaning that quality is based on the customer's experience of consumer credit products as measured by the requirements that the customer wants, the better the quality of a product, it can affect the customer towards product trust. Product quality is determined by its characteristics, functions, and uses. With good and reliable product quality, customers will always remember these products. The results showed that the variable product quality consisting of core products, complementary products, characteristics, and product operators had a significant effect on trust. By displaying the quality of the products produced, customers believe in these products.

\section{Effect of product quality on customer loyalty}

The product quality variable is proven to have a positive effect on customer loyalty. This indicates that consumer credit products offered by Bank BJB increases in quality and following what customers need, thus increasing customer loyalty. Quality consumer credit products reflect the complete range of products available in a banking company, which certainly allows customers to fulfill various banking needs at one bank. This makes consumers reluctant to move to other banks and become loyal.

With higher quality products, the higher customer loyalty. Product quality, which is reflected in the complete range of banking products, enables customers to fulfill various banking needs at one bank, thus creating a tendency not to switch banks. Also, managing multiple accounts in one bank (for example savings, checking, and credit accounts) is easier than having multiple accounts at some different banks, especially supported by mobile banking facilities such as ATMs and banking applications that save time. , energy, and cost. Thus, the completeness of banking products indirectly becomes a switching barrier that prevents customers from switching banks.

The banking industry is an industry with relatively higher switching barriers compared to other industries, such as the consumer product industry. Switching banks can raise several costs that must be borne by the customer. For example, if a customer closes a savings account, several funds must be deposited. It also means consumers have to learn new things at different banks, such as the mobile banking system, bank policies, procedures, and others. The costs that arise are more than just material costs. Thus, banks need to provide a complete range of banking products, 
according to consumer needs, and with competitive interest rates, thereby reducing the tendency of customers to meet their banking needs at other banks.

\section{The effect of customer satisfaction on customer loyalty}

Customer satisfaction variables are proven to have a positive effect on customer loyalty. This shows a positive relationship between customer satisfaction and loyalty. Therefore, the greater the customer or consumer satisfaction, the more loyal the customer is to his choice. The higher the customer satisfaction with service quality, product quality, and transaction experience with the bank, the higher customer loyalty is shown through retention, recommendations, and the bank becomes the main choice of customers for various banking needs.

Based on the variable analysis, customer satisfaction is the main prerequisite for the occurrence of a long-term relationship between the customer and the bank, known as customer loyalty. Increasingly tight bank competition where more and more banks are involved in fulfilling customer needs and desires, causing each bank to place customer satisfaction as the main goal. Loyalty attitudes of customers are affected by beliefs, emotions, and feelings of satisfaction and expectations of the customers themselves. Besides, the bank must be able to change feelings of satisfaction into feelings of pleasure. For the bank, this is a challenge to create a special relationship between the customer and the bank which in the long run will be profitable. The one-to-one approach taken by the bank allows the bank to listen and know that its service offerings support or match the needs/expectations of customers and can immediately respond to customer requests and complaints.

\section{The effect of customer trust on customer loyalty}

Customer trust is proven to have a positive effect on customer loyalty. This indicates that the higher the level of customer trust in the Bank BJB Surabaya Branch Office, the higher the customer loyalty of Bank BJB Surabaya Branch Office. Thus, customer loyalty at Bank BJB Surabaya Branch is affected by customer trust which consists of employee professionalism and a high organizational work ethic. That is, the higher the work standards and commitment of Bank BJB Surabaya Branch Office in providing promised services to customers with confidence, promptness, accuracy, and satisfaction, the higher customer loyalty. In the professional aspect, the high work ethic possessed by bank employees makes customers not doubt the information sourced from the related bank, of course, it will also increase customer loyalty of Bank BJB at the Surabaya Branch Office.

Customer loyalty to Bank BJB Surabaya Branch Office is affected by the trust because customer trust is the belief that a customer finds what he wants from the bank. Trust involves a person's willingness to behave in a certain way because of the belief that his partner will deliver what is expected and an expectation that someone generally has that the words, promises or statements of others can be trusted. The results of the descriptive analysis found that the trust variable was in the high category and loyalty was in the sufficient category.

The level of customer confidence in Bank BJB Surabaya Branch is good and this provides opportunities for Bank BJB Surabaya Branch Offices to increase customer loyalty. Increasing the level of customer confidence can increase customer loyalty to Bank BJB Surabaya Branch Office. In the banking world, the trust factor is a very important factor affecting the level of customer loyalty. Without customer trust in the bank, of course, the bank cannot raise funds from customers. If the trust is lost, the customer will become disloyal to the Bank and vice versa.

Thus, when someone trusts another party in an interpersonal relationship, he will depend on the other party and he will commit the relationship and a commitment like this will bring out his intention to maintain the relationship. Likewise, if a bank customer trusts banking services provided by a bank, the customer has the intention to maintain his relationship with the bank. The 
intention to maintain the relationship between the customer and the bank provided by a bank is represented in the form of customer loyalty.

Product quality against customer loyalty and customer satisfaction as intervening variables

Product quality through customer satisfaction towards customer loyalty has a smaller effect than product quality towards customer loyalty. One important factor that makes customers loyal is the quality of quality and competitive products where if the product is of low quality, the customer will be disloyal to the products we offer. Likewise, customers will become loyal because the products offered are of high quality when compared to products of other competitors. Therefore, the customer satisfaction factor needs to be improved through the products offered. Efforts that can be done are to continue to improve the quality of consumer products that are reliable and sufficiently competitive in the market. The strategy to increase customer loyalty can be done through increasing customer satisfaction by providing quality products.

\section{Product quality on customer loyalty with customer satisfaction as an intervening variable}

Product quality through customer trust towards customer loyalty has a greater effect than product quality towards customer loyalty because the products offered to provide a high sense of customer trust, competence, integrity, and credibility. Provision of the best quality products is a must for the banking world. The higher the quality of the product provided, the higher the customer's trust, so the higher the customer loyalty. Customers feel that the competency of the bank BJB company is quite high with the total assets owned by bank BJB currently as a regional bank with the highest assets when compared to other regional banks so that bank BJB is a bank that can always be counted on. Bank BJB integrity is very high with a culture of clean and transparent work. The main basis for bank activities is trust and is the basic capital of the company to always develop both in raising funds and channeling funds by always prioritizing prudence principle.

Trust is an important asset in increasing consumer loyalty, especially in building long-term relationships. Improving product quality and trust is indirectly followed by increased customer loyalty.

\section{Conclusions and suggestions Conclusion}

Based on the analysis of research results and discussion on the effect of product quality, customer satisfaction, and customer trust on customer loyalty, the following conclusions can be drawn:

1. Product quality contributes to customer satisfaction, i.e. the higher the quality of bank BJB products, the higher customer satisfaction, including customer satisfaction of bank BJB Surabaya Branch Offices in using consumer loans offered to customers. The core value of the product, product complementary and product characteristics, as well as quality product operators, can increase satisfaction for bank BJB consumer credit customers at the Surabaya Branch Office because they can meet customers' expectations of consumer credit products as alternative financing in meeting customer needs.

2. Product quality contributes to customer trust, i.e. the higher the quality of the product provided to customers, the higher the customer trust, where the quality of consumer credit products offered by bank BJB at the Surabaya Branch Office creates high trust from customers. Excellence, convenience, installments and low interest following expectations and not burdening customers. The quality of products offered by bank BJB at the Surabaya branch office is a commitment as a financial institution to help employees who need fresh money.

3. The quality of bank BJB consumer credit products at the Surabaya Branch Office is able to provide comfort and satisfaction for customers so that customer loyalty values do 
not use other bank consumer credit products other than at bank BJB at the Surabaya Branch Office. Also, if a customer faces an urgent need, the customer will not hesitate to immediately add to the ceiling or want to use or follow the products offered by bank BJB according to these needs.

4. Customer satisfaction contributes to customer loyalty. The satisfaction felt by customers forms the values of customer loyalty to bank BJB Surabaya Branch. The higher the satisfaction felt by the customer, the higher the customer loyalty. The convenience in terms of services provided by bank BJB in the Surabaya branch of consumer credit makes customers feel satisfied because all customer expectations can be fulfilled and have an impact on customers to always be loyal to BANK BJB.

5. High customer trust in consumer credit products and commitment of bank BJB Surabaya branch offices also create high loyalty from customers. High work standards, responsibility and commitment of bank BJB at the Surabaya branch office has led to loyal customers to always follow the latest programs from bank BJB.

\section{Suggestion}

Suggestions and contributions of thoughts as input related to the effect of product quality on customer satisfaction, the effect of product quality on customer trust, the effect of product quality on customer loyalty, the effect of customer satisfaction on customer loyalty and the effect of customer trust on customer loyalty, on credit customers bank BJB consumers at the Surabaya Branch Office, including:

1. Being update of customer needs by providing consumer credit products that provide more value than other consumer banking products.

2. Increase speed, competence, comfort, and satisfying complaint handling, so that customers experience improved service.

3. Be more intense in disseminating or notifying customers about the latest loan products given to customers, such as lowering interest rates, direct gift products, and more competitive bank BJB consumer credit products.

4. Optimize training for employees. These efforts are carried out in the hope that there will be an increase in the quality of service provided to customers, especially in answering all customer complaints by enhancing the principles of Good Corporate Governance and Know Your Customer to find solutions to resolve customer needs and complaints.

5. Add information through social media regarding the latest product info from bank bjb.

6. In further research, it is better to use comparisons with similar companies, add variables or use different variables so that the research results are expected to be even better.

\section{References}

Kotler, P., \& Keller, K. L. (2009). Manajemen pemasaran edisi 12 jilid I . Jakarta:Indeks

Kotler, P., \& Keller, K. L. (2009). Manajemen pemasaran edisi 13 jilid I . Jakarta: Erlangga.

Lupiyoadi, R. (2006). Manajemen pemasaran jasa, teori \& praktik. Jakarta: Salemba Empat

Parasuranman, A., Zeithaml, V., \& Berry, L. (1985). A conceptual model of service quality and its implications for future reseach. Journal of retailing, 64 (1), 13-40.

Sugiyono. (2006). Metode penelitian kuantitatif, kualitatif dan R\&D. Bandung: Alfabeta.

Tjiptono, F. (2000). Manajemen jasa. Yogyakarta: Andy.

Tjiptono, F., \& Chandra, G. (2005). Service, quality \& satisfaction. Yogyakarta: Andi 